\title{
Recurrent Painful Ophthalmoplegic Neuropathy: Diagnostic Controversies. Single Case Report with a Systematic Review
}

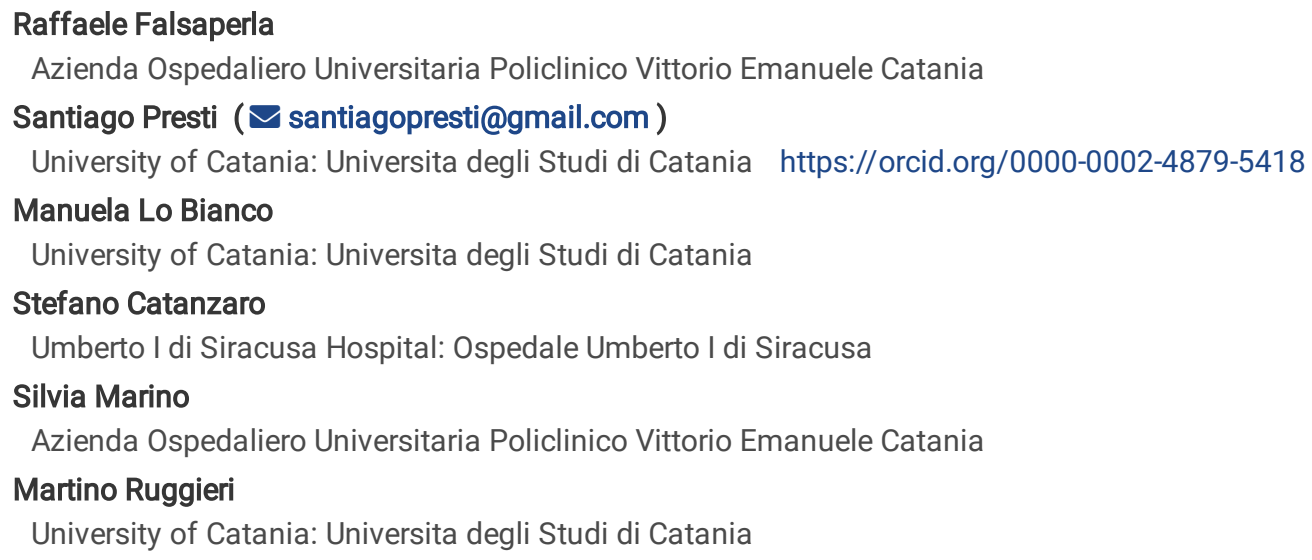

\section{Research Article}

Keywords: Recurrent painful ophthalmoplegic neuropathy, ophthalmoplegic migraine, schwannoma, nerve thickening, ophthalmoplegia, headache

Posted Date: December 3rd, 2021

DOl: https://doi.org/10.21203/rs.3.rs-1088897/v1

License: (c) (i) This work is licensed under a Creative Commons Attribution 4.0 International License. Read Full License 


\section{Abstract}

Background: Ophthalmoplegic migraine, renamed "Recurrent Painful Ophthalmoplegic Neuropathy (RPON) in 2013 by the International Headache Society is a rare neurologic disorder characterized by recurrent attacks of ophthalmoplegia associated to ipsilateral headache. The etiology is still unknown. Typical magnetic resonance imaging findings show a focal nerve thickening and contrast enhancement. In the majority of cases, there is a full recovery within days or weeks. There is no evidence supporting a specific treatment. The review defines the characteristics of the recurrent painful ophthalmoplegic neuropathy in patients within 2 years of age underlying the importance of the role of magnetic resonance imaging even in presence of the first attack. Thus, an emblematic case report is presented.

Case presentation: The authors present a case of third cranial nerve paresis in a 17-month-old male child, presenting a neuroradiological pattern highly suggestive of schwannoma, aneurism or recurrent painful ophthalmoplegic neuropathy. Thus, a review of the literature with the pediatric casuistry of recurrent painful ophthalmoplegic neuropathy occurred within 2 years of age focusing on diagnostic considerations is presented. The authors highlight the importance to consider recurrent painful ophthalmoplegic neuropathy in presence of magnetic resonance imaging findings and clinical symptoms referable to aneurysm or schwannoma. Thus, the review defines the characteristics and the neuroradiological findings at the first RPON attack occurred under 2 years of age.

Conclusion: Although two attacks are necessary, the review strongly suggests to consider recurrent painful ophthalmoplegic neuropathy even at the first attack, in presence of described characteristics and the aforementioned magnetic resonance imaging findings.

\section{Background}

Ophthalmoplegic migraine (OM), renamed "Recurrent Painful Ophthalmoplegic Neuropathy (RPON) in 2013 by the International Headache Society(1) is a rare neurologic disorder characterized by recurrent attacks of ophthalmoplegia associated to ipsilateral headache, that can be migranous or not. In population, incidence is estimated as $0.7 /$ million every year. Laboratory tests such as erythrocythe sedimentation rate, rheumathoid factor, antinuclear antibody, Venereal Disease Research Laboratory (VDRL) and cerebrospinal fluid are normally negative(2). In 80\% of cases it involves the third cranial nerve(3). Typical Magnetic Resonance Imaging (MRI) findings show a focal nerve thickening and contrast enhancement. The etiology of this rare syndrome is still unknown(4). In the majority of cases, there is a full recovery within days or weeks, but less frequently, patients have persistent neurologic deficits (5). According to the International Classification of Headache Disorders (ICHD), it is possible to diagnose RPON/OM with at least 2 attacks of a migraine-like headache associated with paresis of the ocular cranial nerves that occurs within 4 days from the beginning of symptoms. Possible ocular findings are ophthalmoparesis, ptosis, or mydriasis. In order to perform the diagnosis, causes as tumors, infections, and thrombosis must have been excluded (4). According to the aforementioned classification, diagnosing this disorder during the first attack is not possible, even if the MRI findings are highly suggestive of RPON. Specifically, thickening of the interested cranial nerve, with a reduced post-contrast enhancement isa typical pattern. The role of the imaging is challenging because frequently MRI is negative even in case of confirmed RPON.

It is worthy to mention that ocular nerve palsies are rare in childhood(6). Specifically, the third cranial nerve is the less affected in children(7). RPON is one of the rarest causes of third cranial nerve palsy(8). Herein, we report a case of third cranial nerve paresis in a 17-month-old male child, presenting a neuroradiological pattern highly suggestive of schwannoma, aneurism or RPON. Even if the MRI at the first attack was highly suggestive of RPON, the diagnosis according to the ICHD was not possible. Thus, we systematically reviewed the pediatric cases of RPON/OM occurred within 2 years of age comparing them with our case.

\section{Case Presentation}

Herein, we report the case of a 17-month-old male child referred to our Institute presenting gradual onset of mild eyelid ptosis and divergent strabismus of the left eye, preceded two days before by an episode of vomiting. A week prior to the hospitalization, an episode of inconsolable crying, lasting about two hours, occurred with loss of appetite during the following days. Neither fever nor other clinical findings were evident. The patient, third son, was born at term from Cesarean section after pregnancy complicated by placenta previa. Neonatal period was regular. Spherocytosis was diagnosed during the first months of life. His family history revealed spherocytosis (mother and sister) and Hashimoto's thyroiditis (mother). At admission, physical examination was normal, except for eyelid ptosis and lateral deviation of the left eye due to mild medial rectus muscle deficiency and without pupillary dilation, suggesting the involvement of the third cranial nerve. Fundus examination was normal. C-reacting protein (CRP) was negative. Moreover, serological tests and autoimmune panel were negative. Brain magnetic resonance imaging (MRI), enhanced after contrast administration, and magnetic resonance angiography (MRA) were performed. They suggested a vascular anomaly, along the medial side of the left cerebral peduncle, referable to an arterial aneurysm nearby the ipsilateral third cranial nerve (figure 1). However, the angio-CT examination did not confirm the vascular anomaly, highlighting a minimal size irregularity of the P1 tract of the left posterior cerebral artery (figure 2). On the basis of MRI findings, a third cranial nerve neuropathy was suspected. About three weeks after hospital admission, left third oculomotor nerve ophthalmoplegia was no longer appreciable. One month later, a brain MRI was repeated and confirmed a 
sectorial slight thickening of the emergence of the left third cranial nerve, with a reduced post-contrast enhancement compared with the previous exam (figure 3).

One year later, a brain MRI was repeated, showing a complete resolution of the previous neuroradiological lesions (figure 4). In relation to MRI findings and clinical situation, the reported case was highly suggestive of an episode of recurrent painful ophthalmoplegic neuropathy. Nonetheless, according to the diagnostic criteria proposed by the International Classification of Headche Disorders (ICHD) (2018) at least two attacks are necessary to confirm the diagnosis(9). Other considerable, even highly improbable, hypothesis was a schwannoma of the third nerve. For a correct evaluation of the case, we planned a strict follow-up: after 18 months from the diagnosis, the patient had an episode of headache with inconsolable crying treated with paracetamol. During this episode, neurological examination was negative. No other similar episodes with ophtalmoplegia occurred and the neurological examination was negative. After 30 months, the child was conducted at our emergency department presenting again eyelid ptosis and divergent strabismus of the left eye, associated with vomiting and headache. During the hospitalization symptoms gradually resolved spontaneously with a total resolution. This second acute attack confirmed our already strongly suspected diagnosis of RPON.

\section{Discussion And Conclusions}

A diagnosis of RPON is always challeging, especially under 24 months of age. In fact, children are not able to describe headache and the first symptom is often irritability. Our case is highly suggestive of RPON but a definite diagnosis was not possible at the first attack(9).

Third nerve thickening and post-contrast enhancement are suggestive of oculomotor nerve schwannoma, carcinomatosis, granulomatosis, inflammatory or infectious neuritis(10). The case presented was from the beginning highly suggestive for RPON but MRI findings still have no relevance in the diagnostic criteria. Our case reported represents a diagnostic controversial: all symptoms and neuroradiological lesions were highly suggestive but no diagnostic possibilities were admitted during the first attack. In 1997 Wong and Wong(11) suggested to include these MRI findings associated to a single reversible episode of ophthalmoplegia as a supportive diagnostic criteria of RPON. Notwithstanding, neuroradiological imaging during the first episode have only suggested a probable and not a definitive diagnosis so far. It is important to highlight that in our case CT was positive, unlikely Ambrosetto et al.(2) reviewed, showing that CT is normally negative. We systemically reviewed in Pubmed all cases of RPON occurred within 24 months of age and we compared it with our patient. PubMed was searched for all cases of RPON using the search terms "ophthalmoplegic migraine OR recurrent painful ophthalmoplegic neuropathy". Only articles in English or Spanish have been filtered. We performed the PRISMA (Preferred Reporting Items for Systematic Reviews and Meta-Analyses) statement (figure 5). Inclusion criteria were age (up to 24 months), presence of MRI findings and diagnosis of RPON, for these reasons, we excluded 208 records from database searching. Two reviewers independently agreed on selection of eligible studies and achieved consensus on which studies to include. The methodological quality of this systematic review has been assessed using the AMSTAR 2(12) tool as a "low quality review", since no randomized controlled trials (RCTs) are available to date on the scientific literature.

We abstracted the following information: age at onset and current age; sex; cranial nerve (CN) involved (side); headache (side); associated symptoms: photophobia, phonophobia, nausea, vomiting, irritability, other findings; ocular findings: ocular symptoms/signs, diplopia, ophthalmoplegia, palpebral ptosis, pupillary dilation; MRI findings in the acute phase: nerve thickening, post-contrast enhancement; altered cerebrospinal fluid (CSF) if lumbar puncture performed; headache duration; ophthalmoplegia duration; interval between headache onset and ophthalmoplegia; time to resolution of symptoms/signs; therapy in the acute phase; follow-up; prophylactic therapy; control MRI, number of acute episodes; interval between episodes; comorbidity; family history of migraine. The median age at the first attack was 14,3 months. $69,2 \%$ of patients were females and $30,8 \%$ males. The cranial nerve involved was always the third one, except for two patients where it was not mentioned(13). headache was the most frequent symptom, followed by nausea and vomiting. One third of patients presented associated symptoms such as photophobia, phonophobia and irritability. Ocular symptoms/signs were always present: ophthalmoplegia and palpebral ptosis were the most frequent ones, followed by diplopia. Unlikely reported by Huang(3), we found some patient who presented pupillary dilation. It is interesting to highlight the MRI findings: it had been showed a nerve thickening in $61,5 \%$ of cases and a post-contrast enhancement in $53,8 \%$ of patients. In cases where MRI was negative, it is important to understand whether the imaging was really negative or the timing was wrong. In fact, in some patients there is no evidence of MRI abnormalities neither during the interictal phase nor during the first attack and it could only be found after attacks(14). Therapy in acute phase had been administered in $70 \%$ of patients using corticosteroids. In $50 \%$ of cases, at follow-up examination was noted a periodic recurrence of migraine with or without ophthalmoplegia. A limited number of patients (20\%) had permanent neurological damage. Control MRI had been performed in $50 \%$ of cases. It showed in a limited number of patients (20\%) normal findings and in the majority of them (80\%) a persistent enlargement but to a lesser degree. Notably that family history of migraine was positive in $46,1 \%$ of patients and in most cases was on the mother side. We compared the characteristics of our patient with the ones of the review (MRI findings in the acute phase, symptoms and its duration and response to therapy). For the aforementioned reasons, we strongly supported from the first attack that this case was highly suggestive of RPON. We highlight that the first diagnostic hypothesis were aneurysm and schwannoma. Our work let us to extend the knowledge about RPON, suggesting to think at this diagnosis at its very first attack, even in presence of initial MRI findings referable to vascular anomaly or tumors as schwannoma. A relationship between RPON and schwannoma has been often discussed. In 
2019 Petruzzelli et al.(15) reported a patient affected by RPON who developed, after years, a schwannoma of the third cranial nerve. They proposed two explanations of the aforementioned correlation. According to the first one, tumor could intermittently release chemical substances which stimulate trigeminal nerve receptors, leading to the headache. In this case, schwannoma would mimics RPON and it would be an initial manifestation of the tumor, which would be too small to be found in MRI. The second hypothesis, instead, considers RPON as an inflammatory cranial neuralgia and not a migraine. In this case, episodes of inflammation lead to demyelination and remyelination. Schwann cells proliferation could lead to the transformation into schwannoma. As a result, isolated oculomotor schwannoma could be considered as a long-term complication of RPON. Both hypothesis suggest the importance of serial brain MRIs in the long-term follow-up of RPON. In conclusion, our case, compared to the reviewed literature, a diagnosis of RPON was highly suggestive even at the first attack. Our work highlights the importance to consider RPON in presence of MRI findings and clinical symptoms referable to aneurysm or schwannoma. This review defines the characteristics of MRI findings at the first RPON attack occurred under 2 years of age. Although two attacks are necessary, it strongly suggests to consider RPON even at the first attack, in presence of described characteristics. Thus, as mentioned by Wong(11) and Yinglu(14), we suggest to add into the diagnostic criteria the MRI findings, including enhancement and thickening of the nerve involved. We analyzed the relationship between RPON and schwannoma. As proposed by Petruzzelli et al.(15), we are performing a long-term follow-up at our institute in order to prevent any complications.

\section{Abbreviations}

\section{RPON}

recurrent painful ophthalmoplegic neuropathy

OM

ophthalmoplegic migraine

MRI

magnetic resonance imaging

ICHD

International Classification of Headache Disorders

CN

cranial nerve

CSF

cerebrospinal fluid

CT

computed tomography

\section{Declarations}

\section{Ethics approval and consent to participate}

Not applicable

\section{Consent for publication}

Informed consent was obtained from the patient's parents/legal guardians for publication of this case report and any accompanying images.

\section{Competing interests}

The authors declare that they have no competing interests

\section{Funding}

This research received no specific grant from any funding agency in the public, commercial, or not-for-profit sectors.

\section{Authors' contributions}

RF: wrote the case presentation and performed the discussion and conclusion

SP: wrote the case presentation and performed the discussion and conclusion

MLB: analyzed the literature reviewed

SC: performed the review of literature 
SM: wrote the background

MR: overseen the paper

All authors read and approved the final manuscript

\section{Acknowledgements}

Not applicable

Availability of data and materials

PubMed was searched for all cases of RPON using the search terms "ophthalmoplegic migraine OR recurrent painful ophthalmoplegic neuropathy". Only articles in English or Spanish have been filtered

\section{References}

1. Smith SV, Schuster NM. Relapsing Painful Ophthalmoplegic Neuropathy: No longer a "Migraine," but Still a Headache. Curr Pain Headache Rep. 2018 Jul;22(7):50.

2. Ambrosetto P, Nicolini F, Zoli M, Cirillo L, Feraco P, Bacci A. Ophthalmoplegic migraine: From questions to answers. Cephalalgia. 2014 Oct;34(11):914-9.

3. Huang C, Amasanti M, Lovell B, Young T. Recurrent painful ophthalmoplegic neuropathy. Pract Neurol. 2017 Aug;17(4):318-20.

4. Gelfand AA, Gelfand JM, Prabakhar P, Goadsby PJ. Ophthalmoplegic “Migraine” or Recurrent Ophthalmoplegic Cranial Neuropathy: New Cases and a Systematic Review. J Child Neurol. 2012 Jun;27(6):759-66.

5. McMillan HJ, Keene DL, Jacob P, Humphreys P. Ophthalmoplegic Migraine: Inflammatory Neuropathy with Secondary Migraine? Can J Neurol Sci J Can Sci Neurol. 2007 Aug;34(3):349-55.

6. Lyons CJ, Godoy F, ALQahtani E. Cranial nerve palsies in childhood. Eye. 2015 Feb;29(2):246-51.

7. Holmes JM, Mutyala S, Maus TL, Grill R, Hodge DO, Gray DT. Pediatric third, fourth, and sixth nerve palsies: a population-based study. Am J Ophthalmol. 1999 Apr;127(4):388-92.

8. Schumacher-Feero LA, Yoo KW, Mendiola Solari F, Biglan AW. Third cranial nerve palsy in children. Am J Ophthalmol. 1999 Aug;128(2):21621.

9. Headache Classification Committee of the International Headache Society (IHS) The International Classification of Headache Disorders, 3rd edition. Cephalalgia. 2018 Jan;38(1):1-211.

10. Sharifi A, Kayfan S, Clarke RL, Mehta A, Pfeifer CM. Recurrent painful ophthalmoplegic neuropathy: MRI findings in 2 patients. Radiol Case Rep. 2019 Aug;14(8):1039-42.

11. Wong V, Wai Chong Wong. Enhancement of oculomotor nerve: A diagnostic criterion for ophthalmoplegic migraine? Pediatr Neurol. 1997 Jul;17(1):70-3.

12. Shea BJ, Reeves BC, Wells G, Thuku M, Hamel C, Moran J, et al. AMSTAR 2: a critical appraisal tool for systematic reviews that include randomised or non-randomised studies of healthcare interventions, or both. BMJ. 2017 Sep 21;j4008.

13. Carlow TJ. Oculomotor Ophthalmoplegic Migraine: Is It Really Migraine?: J Neuroophthalmol. 2002 Sep;22(3):215-21.

14. Liu Y, Wang M, Bian X, Qiu E, Han X, Dong Z, et al. Proposed modified diagnostic criteria for recurrent painful ophthalmoplegic neuropathy: Five case reports and literature review. Cephalalgia. 2020 Dec;40(14):1657-70.

15. Petruzzelli MG, Margari M, Furente F, Costanza MC, Legrottaglie AR, Dicuonzo F, et al. Recurrent Painful Ophthalmoplegic Neuropathy and Oculomotor Nerve Schwannoma: A Pediatric Case Report with Long-Term MRI Follow-Up and Literature Review. Pain Res Manag. 2019 Sep 25;2019:1-11.

16. Østergaard J, Møller H, Christensen T. Recurrent Ophthalmoplegia in Childhood: Diagnostic and Etiologic Considerations. Cephalalgia. 1996 Jun;16(4):276-9.

17. Ramelli GP, Vella S, Lövblad K, Remonda L, Vassella F. Swelling of the Third Nerve in a Child with Transient Oculomotor Paresis: A Possible Cause of Ophthalmoplegic Migraine. Neuropediatrics. 2000 Jun;31(3):145-7.

18. Lance J, Zagami A. Ophthalmoplegic Migraine: A Recurrent Demyelinating Neuropathy? Cephalalgia. 2001 Mar;21(2):84-9.

19. Weiss AH, Phillips JO. Ophthalmoplegic migraine. Pediatr Neurol. 2004 Jan;30(1):64-6.

20. Bharucha DX, Campbell TB, Valencia I, Hardison HH, Kothare SV. MRI Findings in Pediatric Ophthalmoplegic Migraine: A Case Report and Literature Review. Pediatr Neurol. 2007 Jul;37(1):59-63. 
21. Vecino López R, Rivero JC, Álvarez-Linera Prado J, Noval Martín S. Migraña oftalmopléjica. Valor de la resonancia magnética. An Pediatría. 2009 Jul;71(1):72-5.

22. Vieira JP, Castro J, Gomes LB, Jacinto S, Dias A. Ophthalmoplegic Migraine and Infundibular Dilatation of a Cerebral Artery. Headache J Head Face Pain. 2008 Oct;48(9):1372-4.

23. Riadh H, Mohamed G, Salah Y, Fehmi T, Fafani BHH. Pediatric case of ophthalmoplegic migraine with recurrent oculomotor nerve palsy. Can J Ophthalmol. 2010 Dec;45(6):643.

24. Ghosh PS. Recurrent Right-Sided Ptosis in a Child. JAMA Pediatr. 2015 Jul 1;169(7):693.

\section{Tables}

Table 1. Reports from 1996 to 2007 


\begin{tabular}{|c|c|c|c|c|c|c|c|}
\hline Main features & Østergaard(16) & Østergaard (16) & Ramelli(17) & Lance(18) & Weiss(19) & Carlow(13) & Carlow(13) \\
\hline Age at onset & $18 \mathrm{mo}$ & $7 \mathrm{mo}$ & $20 \mathrm{mo}$ & $9 \mathrm{mo}$ & $24 \mathrm{mo}$ & $18 \mathrm{mo}$ & $18 \mathrm{mo}$ \\
\hline Current age & $8 \mathrm{yr}$ & $19 \mathrm{yr}$ & $8 \mathrm{yr}$ & $16 \mathrm{yr}$ & $7 \mathrm{yr}$ & - & - \\
\hline Sex & $\mathrm{F}$ & $\mathrm{F}$ & $\mathrm{F}$ & $\mathrm{F}$ & M & $\mathrm{F}$ & $\mathrm{F}$ \\
\hline $\begin{array}{l}\text { CN involved } \\
\text { (side) }\end{array}$ & III (L) & $\Pi I(L)$ & III (R) & III (L) & III (L) & - & - \\
\hline Headache (side) & $\begin{array}{l}\text { Yes (starting with } \\
\text { the 2nd episode; } \\
\text { bilateral or left } \\
\text { sided) }\end{array}$ & $\begin{array}{l}\text { Yes (starting } \\
\text { with her 5th } \\
\text { episode; left- } \\
\text { sided and eye } \\
\text { pain) }\end{array}$ & $\begin{array}{l}\text { Yes (starting } \\
\text { with the } 2 \text { nd } \\
\text { episode at } \\
\text { the age of } 6 \\
\text { yr and } 8 \text { mo } \\
\text { after a fall } \\
\text { backwards } \\
\text { - no } \\
\text { apparent } \\
\text { headache at } \\
\text { 1st episode) }\end{array}$ & $\begin{array}{l}\text { Yes (behind } \\
\text { the left eye, } \\
\text { described as } \\
\text { sharp and } \\
\text { fluctuating in } \\
\text { intensity) }\end{array}$ & $\begin{array}{l}\text { Yes ( } L ; \\
\text { supraorbital) }\end{array}$ & Yes & Yes \\
\hline $\begin{array}{l}\text { Associated } \\
\text { symptoms }\end{array}$ & No & Yes & No & Yes & No & - & - \\
\hline Photophobia & - & - & - & Yes & - & - & - \\
\hline Phonophobia & - & - & - & Yes & - & - & - \\
\hline Nausea & - & - & - & Yes & - & - & - \\
\hline Vomiting & - & Yes & - & $\begin{array}{l}\text { Yes } \\
\text { (sometimes) }\end{array}$ & - & - & - \\
\hline Irritability & - & Yes & - & - & - & - & - \\
\hline \multirow[t]{2}{*}{ Other findings } & $\begin{array}{l}\text { Signs of varicella } \\
\text { infection at 2nd } \\
\text { episode }\end{array}$ & Drowsiness & - & $\begin{array}{l}\text { Attacks of } \\
\text { screaming }\end{array}$ & - & - & - \\
\hline & $\begin{array}{l}\text { Dizziness at } 4 \text { th } \\
\text { episode }\end{array}$ & & & & & & \\
\hline $\begin{array}{l}\text { Ocular } \\
\text { symptoms/signs }\end{array}$ & Yes & Yes & Yes & Yes & Yes & - & - \\
\hline Diplopia & NS & NS & Yes & NS & Yes & - & - \\
\hline Ophthalmoplegia & $\begin{array}{l}\text { Yes (not always } \\
\text { present) }\end{array}$ & Yes & Yes & Yes & Yes & - & - \\
\hline Palpebral ptosis & Yes & Yes & Yes & Yes & Yes & - & - \\
\hline Pupillary dilation & $\begin{array}{l}\text { Yes (poorly } \\
\text { reactive pupil to } \\
\text { light) }\end{array}$ & Yes & $\begin{array}{l}\text { Yes (poorly } \\
\text { reactive to } \\
\text { light) }\end{array}$ & $\begin{array}{l}\text { Yes (reactive } \\
\text { to light with } \\
\text { progression } \\
\text { to } \\
\text { unresponsive } \\
\text { pupil) }\end{array}$ & $\begin{array}{l}\text { Yes (sluggish } \\
\text { response to } \\
\text { light) }\end{array}$ & No & Yes \\
\hline $\begin{array}{l}\text { MRI findings in } \\
\text { the } \\
\text { acute phase }\end{array}$ & $\begin{array}{l}\text { MRI perfomerd } \\
12 \text { days later 2nd } \\
\text { episode onset } \\
\text { (ptosis partially } \\
\text { resolved) }\end{array}$ & Not performed & $\begin{array}{l}\text { Yes - At } \\
\text { second } \\
\text { episode (not } \\
\text { performed } \\
\text { at the 1st } \\
\text { episode) }\end{array}$ & Yes & $\begin{array}{l}\text { Yes - } \\
\text { performed after } \\
2 \text { weeks of } \\
\text { onset (several } \\
\text { foci of white } \\
\text { matter } \\
\text { hyperintensity } \\
\text { measuring } 3 \\
\text { mm or less } \\
\text { identified in the } \\
\text { dorsal } \\
\text { periventricular } \\
\text { region) }\end{array}$ & Yes & Yes \\
\hline Nerve thickening & $\begin{array}{l}\text { Yes (from the } \\
\text { brainstem } \\
\text { through the } \\
\text { prepontin cistern }\end{array}$ & - & Yes & No & No & Yes & Yes \\
\hline
\end{tabular}




\begin{tabular}{|c|c|c|c|c|c|c|}
\hline $\begin{array}{l}\text { Post-contrast } \\
\text { enhancement }\end{array}$ & Yes & - & Yes & $\begin{array}{l}\text { Yes - at the } \\
\text { point of exit } \\
\text { of the nerve } \\
\text { from the } \\
\text { midbrain, } \\
\text { continuing } \\
\text { along the line } \\
\text { of the nerve }\end{array}$ & No & Yes \\
\hline
\end{tabular}

\begin{tabular}{|c|c|c|c|c|c|c|c|}
\hline $\begin{array}{l}\text { Altered CSF if } \\
\text { lumbar } \\
\text { puncture } \\
\text { performed }\end{array}$ & No (2nd episode) & No & No & NS & - & - & - \\
\hline $\begin{array}{l}\text { Headache } \\
\text { duration }\end{array}$ & 3-4 days & NS & NS & NS & NS & - & - \\
\hline $\begin{array}{l}\text { Ophthalmoplegia } \\
\text { duration }\end{array}$ & NS & NS & NS & NS & NS & - & - \\
\hline $\begin{array}{l}\text { Interval between } \\
\text { headache onset } \\
\text { and } \\
\text { ophthalmoplegia }\end{array}$ & 3-4 days & 1 day & $\begin{array}{l}4 \text { days } \\
\text { (second } \\
\text { episode) }\end{array}$ & $\begin{array}{l}\text { NS }-3-4 \\
\text { days between } \\
\text { headache } \\
\text { and palpebral } \\
\text { ptosis }\end{array}$ & NS & - & - \\
\hline $\begin{array}{l}\text { Time to } \\
\text { resolution of } \\
\text { Symptoms/Signs }\end{array}$ & 6-8 weeks & $\begin{array}{l}6 \text { mo (1st } \\
\text { episode) }\end{array}$ & $\begin{array}{l}\text { Within } 2 \\
\text { weeks (first } \\
\text { episode) }\end{array}$ & $\begin{array}{l}\text { From few } \\
\text { days }(2-11) \\
\text { to } 2 \text { months }\end{array}$ & NS & - & - \\
\hline $\begin{array}{l}\text { Therapy in the } \\
\text { acute phase }\end{array}$ & $\begin{array}{l}\text { Prednisone } \\
\text { ( } 2 \mathrm{mg} / \mathrm{kg} / \text { day) for } \\
\text { about } 10 \text { days } \\
\text { with apparent } \\
\text { response }\end{array}$ & NS & NS & NS & - & - & - \\
\hline Follow-up & $\begin{array}{l}\text { Yes ( refered } \\
\text { migraine attacks } \\
\text { without } \\
\text { ophthalmoplegia) }\end{array}$ & $\begin{array}{l}\text { Yes (permanent } \\
\text { partial III CN } \\
\text { palsy) }\end{array}$ & - & $\begin{array}{l}\text { Yes (with } \\
\text { apparent } \\
\text { decreased } \\
\text { number of } \\
\text { episodes ) }\end{array}$ & NS & - & - \\
\hline $\begin{array}{l}\text { Prophylactic } \\
\text { therapy }\end{array}$ & - & $\begin{array}{l}\text { Propranolol } \\
\text { Metoclopramide } \\
\text { Diazepam } \\
\text { Acetaminophen }\end{array}$ & - & $\begin{array}{l}\text { Cafergot; } \\
\text { Aspirin; } \\
\text { Amitriptyline; } \\
\text { Pizotifen; } \\
\text { Flunarizine ( } \\
10 \text { mg/day } \\
\text { with apparent } \\
\text { response) }\end{array}$ & NS & - & - \\
\hline Control MRI & $\begin{array}{l}\text { Performed after } 3 \\
\text { months of the 3rd } \\
\text { episode onset } \\
\text { (persistent } \\
\text { enlargement of III } \\
\text { CN but to a lesser } \\
\text { degree) }\end{array}$ & $\begin{array}{l}\text { MRIs at 14, 15, } \\
\text { 16-years-of-age } \\
\text { showing } \\
\text { persistent } \\
\text { enlargement } \\
\text { (from the } \\
\text { brainstem } \\
\text { through the } \\
\text { prepontin cistern } \\
\text { to the } \\
\text { carvernous } \\
\text { sinus) }\end{array}$ & NS & $\begin{array}{l}\text { A repeat MRI } \\
\text { scan showed } \\
\text { enhancement } \\
\text { of the } \\
\text { oculomotor } \\
\text { nerve still } \\
\text { present but } \\
\text { less intense; } \\
\text { unenhanced } \\
\text { MRls of the } \\
\text { brain at the } \\
\text { ages of } 12 \\
\text { and } 14 \text { years } \\
\text { were normal }\end{array}$ & - & - & - \\
\hline $\begin{array}{l}\text { Number of acute } \\
\text { episodes }\end{array}$ & $\begin{array}{l}\text { NS ( about four } \\
\text { episodes) }\end{array}$ & NS & NS & $\begin{array}{l}\text { NS - About } \\
38 \text { episodes }\end{array}$ & - & - & - \\
\hline $\begin{array}{l}\text { Interval between } \\
\text { episodes }\end{array}$ & $\begin{array}{l}\text { Range } 15 \text { mo }-3 \\
\text { yr }\end{array}$ & 6-9 mo & NS & NS & - & - & - \\
\hline
\end{tabular}




$\begin{array}{|llllll|}\text { Comorbidity } & \text { Migraine } & - & \begin{array}{l}\text { Migraine } \\ \text { without aura }\end{array} & \text { Migraine } \\ \begin{array}{l}\text { Family history of } \\ \text { migraine }\end{array} & \text { No } & \text { No } & \begin{array}{l}\text { Yes (on the } \\ \text { maternal } \\ \text { side) }\end{array} & \begin{array}{l}\text { Yes (on the } \\ \text { maternal } \\ \text { side) }\end{array} & \text { No }\end{array}$

Table 2. Reports from 2007 to 2015 


\begin{tabular}{|c|c|c|c|c|c|c|}
\hline Main features & McMillan(5) & Bharucha(20) & $\begin{array}{l}\text { Vecino } \\
\text { López(21) }\end{array}$ & Vieira(22) & Riadh(23) & Ghosh(24) \\
\hline Age at onset & $12 \mathrm{mo}$ & $18 \mathrm{mo}$ & Before 6 mo & $9 \mathrm{mo}$ & $9 \mathrm{mo}$ & $18 \mathrm{mo}$ \\
\hline Current age & $6 \mathrm{yr}$ & $16 \mathrm{yr}$ & $\begin{array}{l}3 \mathrm{yr} \text { and } 11 \\
\mathrm{mo}\end{array}$ & $7 \mathrm{yr}$ & $3 y r$ & NS \\
\hline Sex & $M$ & $\mathrm{~F}$ & $\mathrm{~F}$ & M & $\mathrm{F}$ & $M$ \\
\hline $\begin{array}{l}\text { CN involved } \\
\text { (side) }\end{array}$ & III (L) & III (R) & $\| I I(R)$ & III(R) & $\operatorname{III}(\mathrm{L})$ & $\operatorname{II}(\mathrm{R})$ \\
\hline Headache (side) & $\begin{array}{l}\text { Yes (starting with } \\
\text { his 4th episode) }\end{array}$ & Yes (R) & - & $\begin{array}{l}\text { Yes(R, } \\
\text { frontotemporal } \\
\text { and orbital } \\
\text { pain) }\end{array}$ & $\operatorname{Yes}(\mathrm{L})$ & $\begin{array}{l}\text { Yes(starting with } \\
\text { 2nd episode) }\end{array}$ \\
\hline $\begin{array}{l}\text { Associated } \\
\text { symptoms }\end{array}$ & No & No & - & Yes & Yes & No \\
\hline Photophobia & - & - & - & Yes & - & - \\
\hline Phonophobia & - & - & - & Yes & - & - \\
\hline Nausea & - & - & - & Yes & Yes & - \\
\hline Vomiting & - & - & - & $\begin{array}{l}\text { Yes(occasional- } \\
\text { ly during the } \\
\text { first days of a } \\
\text { episode) }\end{array}$ & Yes & - \\
\hline Irritability & - & - & - & - & - & - \\
\hline Other findings & - & - & - & - & $\begin{array}{l}\text { Yes } \\
\text { (abdominal } \\
\text { pain) }\end{array}$ & - \\
\hline $\begin{array}{l}\text { Ocular } \\
\text { symptoms/signs }\end{array}$ & Yes & Yes & Yes & Yes & Yes & Yes \\
\hline Diplopia & - & Yes & NS & NS & - & $\begin{array}{l}\text { Yes (starting with } \\
\text { 2nd episode) }\end{array}$ \\
\hline Ophthalmoplegia & Yes & Yes & Yes & Yes & Yes & No \\
\hline Palpebral ptosis & Yes & Yes & Yes & Yes & Yes & Yes \\
\hline Pupillary dilation & $\begin{array}{l}\text { No - During his } \\
\text { fourth episode, at } \\
\text { 29-months-of-age, } \\
\text { the authors } \\
\text { describe a left } \\
\text { sluggish pupil } \\
\text { response }\end{array}$ & $\begin{array}{l}\text { Yes (not reactive to } \\
\text { light) }\end{array}$ & $\begin{array}{l}\text { Yes (sluggish } \\
\text { pupil response }\end{array}$ & Yes & $\begin{array}{l}\text { Yes (mildly } \\
\text { dilated, } \\
\text { reactive to } \\
\text { light) }\end{array}$ & No \\
\hline $\begin{array}{l}\text { MRI findings in } \\
\text { the } \\
\text { acute phase }\end{array}$ & Yes & $\begin{array}{l}\text { Yes (during last } \\
\text { episode on the day } \\
\text { of onset of } \\
\text { symptoms; all } \\
\text { previous MRI } \\
\text { exams had yielded } \\
\text { normal findings }\end{array}$ & Yes & $\begin{array}{l}\text { Yes } \\
\text { (infundibular } \\
\text { dilatation of a } \\
\text { perforating } \\
\text { branch of the } \\
\text { posterior } \\
\text { cerebral artery } \\
\text { emerging just } \\
\text { above the } \\
\text { superior } \\
\text { cerebellar } \\
\text { artery, adjacent } \\
\text { to the affected } \\
\text { nerve) }\end{array}$ & No & Yes \\
\hline Nerve thickening & $\begin{array}{l}\text { Yes - at the forth } \\
\text { episode ( } 29 \text { mo of } \\
\text { age; cisternal part } \\
\text { of nerve root) }\end{array}$ & $\begin{array}{l}\text { Yes (at nerve root } \\
\text { origin) }\end{array}$ & $\begin{array}{l}\text { Yes (cisternal } \\
\text { part) }\end{array}$ & No & - & $\begin{array}{l}\text { Yes [cisternal part } \\
\text { - performed at } 18 \\
\text { mo(first episode)] }\end{array}$ \\
\hline $\begin{array}{l}\text { Post-contrast } \\
\text { enhancement }\end{array}$ & $\begin{array}{l}\text { Yes - during first } \\
\text { episode ( } 12 \text { mo of }\end{array}$ & $\begin{array}{l}\text { Yes (at nerve root } \\
\text { origin) }\end{array}$ & No & No & - & No \\
\hline
\end{tabular}


age; at the site of exit of nerve root) and forth episode (29 mo of age; cisternal part of nerve root)

\begin{tabular}{|c|c|c|c|c|c|c|}
\hline $\begin{array}{l}\text { Altered CSF if } \\
\text { lumbar } \\
\text { puncture } \\
\text { performed }\end{array}$ & No & $\begin{array}{l}\text { No (during last } \\
\text { episode) }\end{array}$ & NS & NS & NS & No \\
\hline $\begin{array}{l}\text { Headache } \\
\text { duration }\end{array}$ & $\begin{array}{l}2-3 \text { days (4th } \\
\text { episode) }\end{array}$ & NS & - & 3-7 days & NS & $\begin{array}{l}\text { 6-7 days (before } \\
\text { development of } \\
\text { ptosis }\end{array}$ \\
\hline $\begin{array}{l}\text { Ophthalmoplegia } \\
\text { duration }\end{array}$ & $\begin{array}{l}\text { From } 2-3 \text { days (1st } \\
\text { episode) to } 2-3 \\
\text { weeks ( } 4 \text { th } \\
\text { episode) }\end{array}$ & NS & $3 \mathrm{mo}$ & $\begin{array}{l}\text { 2-5 days } \\
\text { (initially) } \\
\text { 1-4 weeks }\end{array}$ & NS & - \\
\hline $\begin{array}{l}\text { Interval between } \\
\text { headache onset } \\
\text { and } \\
\text { ophthalmoplegia }\end{array}$ & $\begin{array}{l}2-3 \text { days ( } 4 \text { th } \\
\text { episode) }\end{array}$ & $\begin{array}{l}\text { Within } 6 \text { hours of } \\
\text { onset }\end{array}$ & NS & $\begin{array}{l}\text { At onset of } \\
\text { pain }\end{array}$ & NS & - \\
\hline $\begin{array}{l}\text { Time to } \\
\text { resolution of } \\
\text { Symptoms/Signs }\end{array}$ & $\begin{array}{l}\text { From 2-3 days ( } 1 \text { st } \\
\text { episode) to } 2-3 \\
\text { weeks (4th } \\
\text { episode)-The } \\
\text { authors describe } \\
\text { periodic recurrence } \\
\text { with each episode } \\
\text { taking longer to } \\
\text { recupera-te }\end{array}$ & $\begin{array}{l}\text { Within } 1 \text { week of } \\
\text { symptom onset } \\
\text { (last episode) }\end{array}$ & $\begin{array}{l}3 \text { mo (the } \\
\text { authors report } \\
\text { the use of } \\
\text { botulinum } \\
\text { toxin for } \\
\text { squint) }\end{array}$ & 1-4 weeks & NS & $\begin{array}{l}3 \text { weeks (1st } \\
\text { episode) }\end{array}$ \\
\hline $\begin{array}{l}\text { Therapy in the } \\
\text { acute phase }\end{array}$ & $\begin{array}{l}\text { Prednisone }(2 \mathrm{mg} / \mathrm{kg} \\
\text { for } 10 \text { days) with } \\
\text { tapering over the } \\
\text { following week and } \\
\text { apparent response }\end{array}$ & $\begin{array}{l}\text { Methylprednisolone } \\
\text { iv } 25 \mathrm{mg} / \mathrm{Kg} \text { for } 5 \\
\text { days (at last } \\
\text { episode, started } \\
\text { immediately on the } \\
\text { first day of onset) }\end{array}$ & $\begin{array}{l}\text { Oral } \\
\text { corticosteroids }\end{array}$ & $\begin{array}{l}\text { Oral prednisone } \\
\text { (1 mg/kg/day) } \\
\text { with apparent } \\
\text { response } \\
\text { This treatment } \\
\text { was used twice } \\
\text { and the pain } \\
\text { subsided much } \\
\text { earlier (within } \\
\text { 24-48 hours) }\end{array}$ & $\begin{array}{l}3 \text { pulses of } \\
\text { methyl- } \\
\text { prednisolone } \\
\text { followed by } \\
\text { an oral } \\
\text { steroid } \\
\text { therapy ( } 1 \\
\mathrm{mg} / \mathrm{kg} / \mathrm{day}) \\
\text { for } 1 \text { week } \\
\text { with gradual } \\
\text { tapering } \\
\text { over } 6 \text { weeks }\end{array}$ & $\begin{array}{l}\text { Methylprednisolone } \\
\text { iv } 30 \mathrm{mg} / \mathrm{Kg} \text { for } 3 \\
\text { days ( } 1 \mathrm{st} \text { episode); } \\
\text { Immunoglobulin iv } \\
2 \mathrm{~g} / \mathrm{kg} \text { for } 2 \text { days } \\
\text { (2nd episode) }\end{array}$ \\
\hline Follow-up & $\begin{array}{l}\text { At the age of } 6 \\
\text { years, periodic } \\
\text { recurrence of } \\
\text { complete left III CN } \\
\text { paresis, with each } \\
\text { episode taking } \\
\text { longer to recuperate } \\
\text { - episodes of } \\
\text { migraine without } \\
\text { aura - permanent } \\
\text { neurological } \\
\text { damage with } \\
\text { relative mydriasis } \\
\text { (reactive to light) }\end{array}$ & & Yes & $\begin{array}{l}\text { Yes ( not fully } \\
\text { recovering from } \\
\text { ophthalmople- } \\
\text { gia) }\end{array}$ & No episodes & $\begin{array}{l}\text { Normal neurologic } \\
\text { examination }\end{array}$ \\
\hline $\begin{array}{l}\text { Prophylactic } \\
\text { therapy }\end{array}$ & $\begin{array}{l}\text { Pizotifen (beneficial } \\
\text { for migraine,not for } \\
\text { ophthalmople-gia) }\end{array}$ & & - & $\begin{array}{l}\text { Flunarizine } \\
\text { (decreased } \\
\text { number of } \\
\text { episodes) }\end{array}$ & - & - \\
\hline Control MRI & $\begin{array}{l}\text { MRI at } 15 \text { mo of } \\
\text { age with normal }\end{array}$ & $\begin{array}{l}\text { Yes (at } 3 \text { and } 7 \\
\text { months after the }\end{array}$ & $\begin{array}{l}\text { MRI after four } \\
\text { mo of onset }\end{array}$ & NS & - & - \\
\hline
\end{tabular}




\begin{tabular}{|c|c|c|c|c|c|c|}
\hline & findings & $\begin{array}{l}\text { onset of symptoms } \\
\text { with demonstrated } \\
\text { reversal of } \\
\text { abnormalities) }\end{array}$ & $\begin{array}{l}\text { (reduced III CN } \\
\text { enlargement) }\end{array}$ & & & \\
\hline $\begin{array}{l}\text { Number of acute } \\
\text { episodes }\end{array}$ & $\begin{array}{l}\text { NS ( the authors } \\
\text { describes surely } \\
\text { foru episodes at } 12 \text {, } \\
17,23 \text { and } 29- \\
\text { months-of-age) }\end{array}$ & 8 & NS & NS & $\begin{array}{l}4(9 \mathrm{mo}, 1 \mathrm{y} \\
2 \mathrm{y}, 3 \mathrm{y})\end{array}$ & 3 ( 18mo, 3y, 5y) \\
\hline $\begin{array}{l}\text { Interval between } \\
\text { episodes }\end{array}$ & NS & - & NS & $\begin{array}{l}\text { From weeks to } \\
\text { months }\end{array}$ & $\begin{array}{l}\text { Range 3-12 } \\
\text { mo }\end{array}$ & Range $16-24 \mathrm{mo}$ \\
\hline Comorbidity & No & No & - & No & - & - \\
\hline $\begin{array}{l}\text { Family history of } \\
\text { migraine }\end{array}$ & No & - & - & $\begin{array}{l}\text { Yes (on the } \\
\text { maternal side) }\end{array}$ & Yes & $\begin{array}{l}\text { Yes (on the } \\
\text { maternal side) }\end{array}$ \\
\hline
\end{tabular}

\section{Figures}

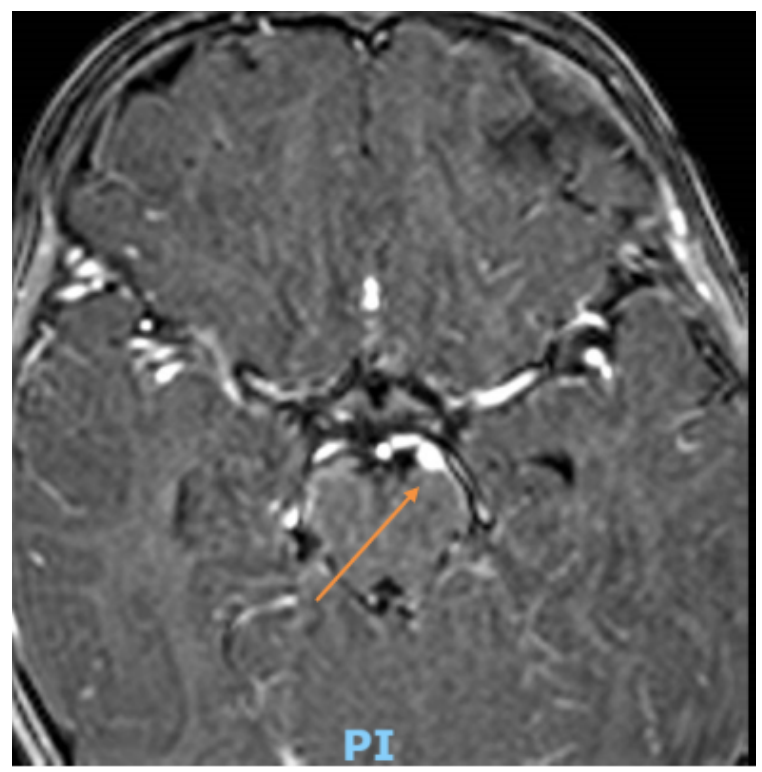

\section{Figure 1}

First MRI wrongly suggestive for an aneurism along the medial side of the left cerebral peduncle

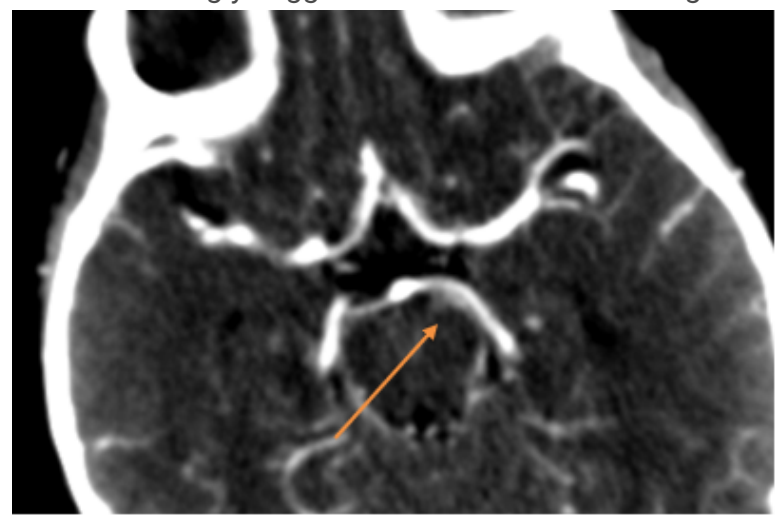

\section{Figure 2}

Minimal size irregularity of the P1 tract of the left posterior cerebral artery 


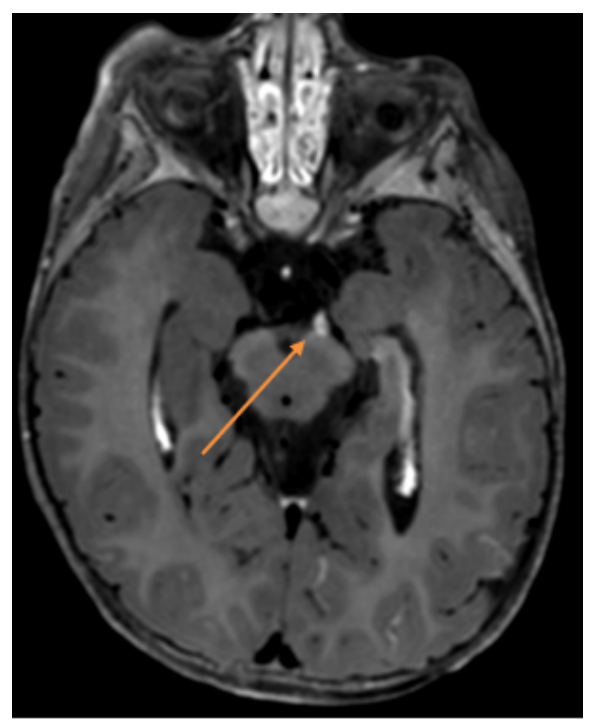

\section{Figure 3}

Sectorial slight thickening of the emergence of the left third cranial nerve, with a reduced post-contrast enhancement compared with the previous exam

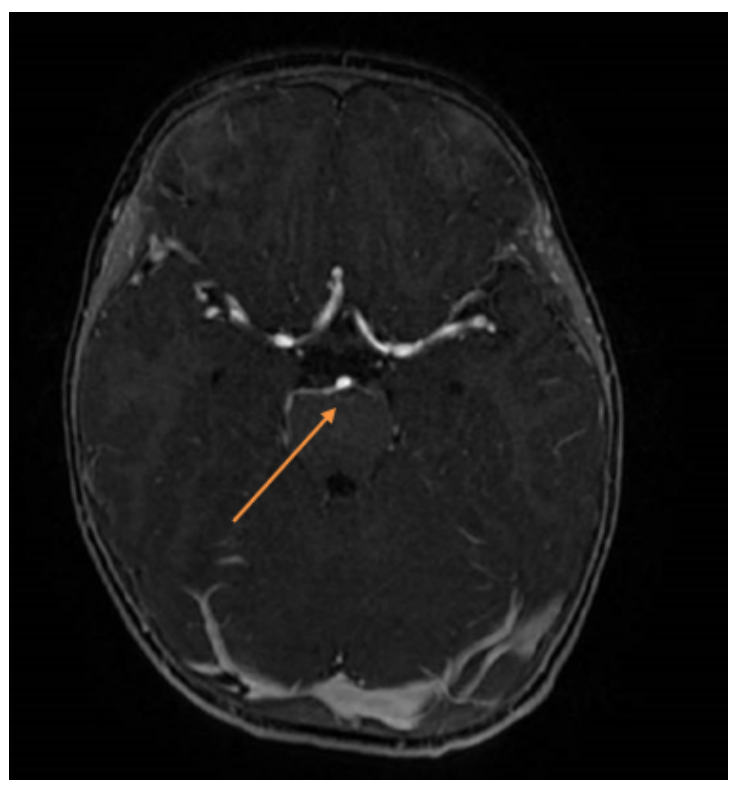

\section{Figure 4}

Complete resolution of the previous neuroradiological lesions 
$\mathrm{N}^{\circ}$ of records identified through database searching: 219

\section{SCREENING}

$\mathrm{N}^{\circ}$ of records screened: $\mathbf{2 1 1}$

$N^{\circ}$ of records excluded: 196

\section{ELIGIBILITY}

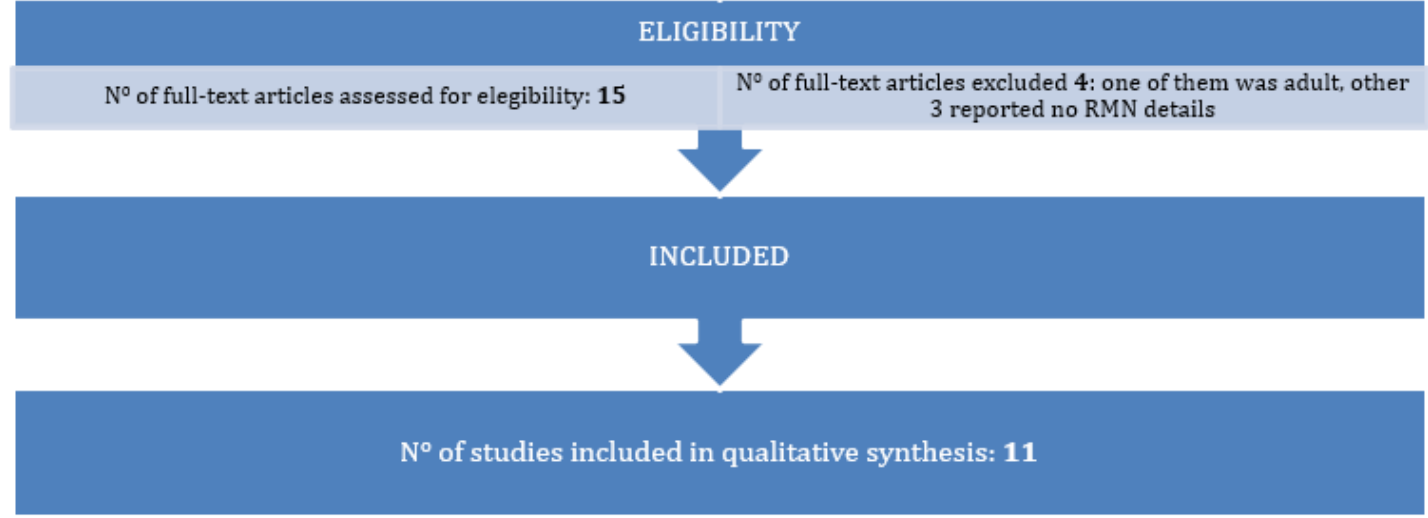

\section{Figure 5}

PRISMA (Preferred Reporting Items for Systematic Reviews and Meta-Analyses) statement 